\title{
Strategies and Technological Advances in Removing Space Debris Satellite
}

\author{
S. Philomina, B. Hemalatha, R. Hema
}

\begin{abstract}
Now days we are sending many satellites into the space which are mainly useful for communication. Till now we have sent many satellites and we have dropped many things in the space like those dead particles revolves around the earth in Low Earth Particles (LEO). This derbis became a problem. It will be a risk to other particles which are revolving in LEO. If we doesn't take any steps it will lead to collisions and destroy all communication system. The Japan Aerospace Exploration Agency (JAXA) Aerospace Research is studying a micro-satellite space derbi removal scheme. This paper discuss about the Key technologies, strategies and specifications of removing derbis satellite.
\end{abstract}

KEY WORDS: JAXA, Piggyback, EDT, star tracker, stereo vision, LEO, Rendezvous sensors, JEM, JCAP, STEP, Thrusters.

\section{INTRODUCTION}

Moon is a natural satellite for earth. Satellites are used for communication purpose. Japan Aerospace Exploration Agency (JAXA) Aerospace Research is studying the removal of derbis from orbit Generally, it comprises of tiny spacecraft (a micro-satellite capable of piggyback launches with other playloads).

Hundreds of millions of space craft are orbiting the earth at a speed of several kilometers per second. Showing that these space craft will become a major issue for the next few years. Generally, the study demonstrates that, if beings do not take any action to regulate the derbis, it leads to the crash of spacecraft.This contributes to the destruction of the Earth's communication scheme. For example, the Global Positioning System (GPS), the navigation signals are the main components of this global economy model. GPS failure will disrupt all emergency reaction facilities, banking systems, and power grids[1],[3],[5]. This satellite will transfer big derbis items that occupy Low Earth orbits to the disposal orbit. Electro-Dynamic Tether (EDT) technique is being tested as a strong orbital transfer scheme for this idea. This EDT scheme is used to deorbitalize the derbi.

Revised Manuscript Received on August 22, 2019.

S. Philomina, Department of Electronics and Communication Engineering, Bharath Institute of Higher Education and Research, Chennai, Tamilnadu, India. E Mail - philomina.nov83@gmail.com

B. Hemalatha, Department of Electronics and Communication Engineering, Bharath Institute of Higher Education and Research, Chennai, Tamilnadu, India. E Mail - contacthemab@gmail.com

R. Hema, Department of Electronics and Communication Engineering, Bharath Institute of Higher Education and Research, Chennai, Tamilnadu, India. E Mail - hemrbujradha@gmail.com

\section{ECONOMICAL SURVEY}

Generally, the term space derbis referred for the natural derbis present in the solar system I.e, asteroids, comets and meteoroids. In 1957, Hams Patterson, is the first person founded there is a measurements of the fall of space dust on the, estimating to be $14,30,000$ tons per year. After that in 1979 , NASA was studying over this, they founded there is space debris in earth's orbit i.e, dead space crafts, rockets. They estimated that if it raises like this it will lead to collisions[2],[4],[6].

As of 5 July 2016, the strategies of the United States tracked almost 17,852 artificial objects in Earth orbit.

Practically, there is 6,800 tons of space derbis in our Earths orbit. Moreover that 23,000 tracked objects and 26,000 untracked $(<10 \mathrm{~cm})$ objects are present in Earths orbit.
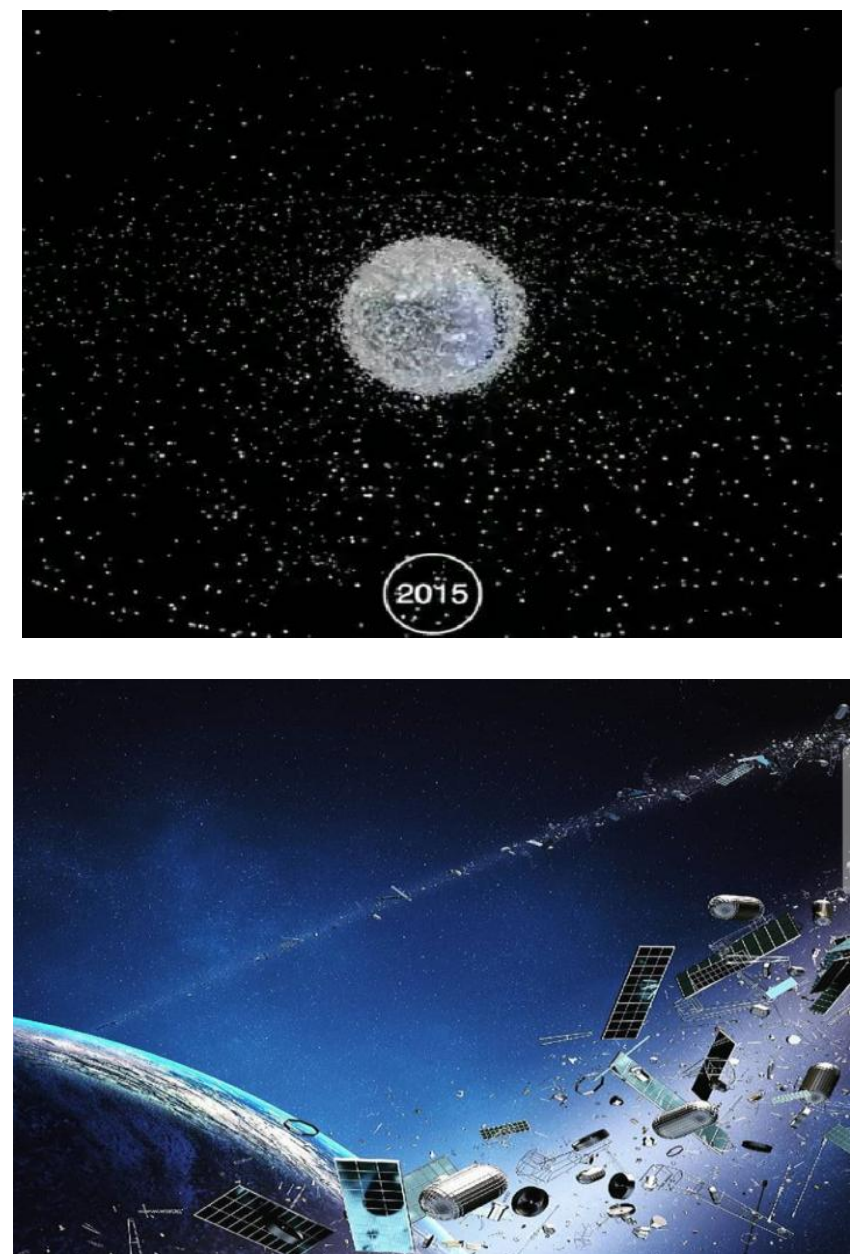


\section{Method FOR REMoving SATELlite DERbis}

Generally speaking, satellites occupy either the Low Earth Orbit or the Geo-Stationary Orbit. Space craft and Rocket upper stages in GSO shall be removed by de-orbitilization at an altitude of up to $650 \mathrm{~km}$ or less in 25 years from which they shall re-enter the atmosphere and burn[7],[9],[11].

\section{TARGET FOR RETRIEVAL / REMOVAL}

The impact of the Earth's gravitational field is powerful in LEO. So, we can use an electro dynamic tether to produce a thrust to decrease the orbit[8],[10],[12].

Low Earth Orbits are efficient in Earth Observation. (Specially in Sun-Synchronous Orbits) there is a danger of spacecraft collision. In order for measures to be taken to decrease the amount of spacecraft, rockets are in the upper phases of such orbits. In this consideration, JAXA is researching a system with technology of retrival and removal of satllite derbis from low earth orbits.

\section{Strategy}

Many number of satellites remain in ISO and GSO Orbits from past launches and this becomes a derbis in Orbits. This micro satellite will retrive and removed debris from orbitales. This micro-satellite transfers the derbis to reduced orbits and also removes the object by catching it using a robot arm and then de-orbiting it[13],[15],[17].

The following strategies which are used for removal.

a. A piggy back launch of the derbi removal will monitor low earth orbit satellites that are helpful for Earth observation.

b. The use of electrodynamic tethers generates a thrust for reducing the orbit.

c. The Robot Capture at the other end of the tether. The body of the car itself is the tip mass of the tether.

\section{OPERATIONS}

Removing Debris satellites will dock with International Space Station (ISS) which is present in Low Earth Orbit (LEO). It will release a Japanese Experiment module(JEM) This contains four operations.

1. Net Capture: throwing a net on derbis and De-orbitalise it. 2. Vision-based-navigation : Robotic vision will check the status of the derbis.

3. Harpoon capture : It is designed to capture the space-junk. 4. Drag soil : This soil will drags the derbis to de orbits within eight weeks of deployment

\section{KEY TECHNOLOGIES FOR SDMR}

a. The following main techniques are needed to remove the derbis satellite.

b. Orbital transfer technology. Navigation around space craft (or) derbis : vision capture/image processsing

c. Robotic Arm Capture : This will capture the derbis object
SPECIFICATIONS OF THE SDMR

\begin{tabular}{|l|l|l|}
\hline Item & Specification & Remarks \\
\hline Dimensions & $700 * 700 * 600 \mathrm{~mm}$ & \\
\hline Weight & $140 \mathrm{~kg}$ & Fuel:25kg \\
\hline Power & $100 \mathrm{w}$ & Average \\
\hline Attitude control & 3 -axis control & 3 wheels \\
\hline Thrusters & IN*8 & \\
\hline $\begin{array}{l}\text { Rendezvous } \\
\text { sensors }\end{array}$ & $\begin{array}{l}\text { GPS receiver } \\
\text { Star tracker } \\
\text { Stereo vision }\end{array}$ & \\
\hline
\end{tabular}

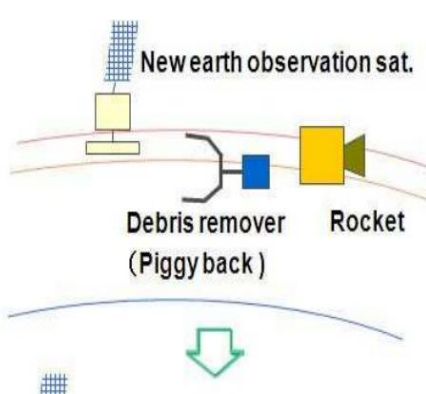

New earth observation sat.

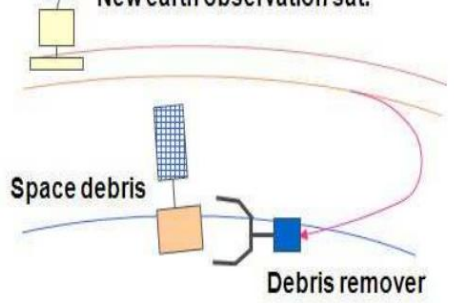

1) Observation of target motion

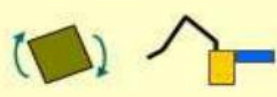

2) Rotation braking by robot arm

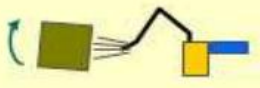

3) Capture by robot arm

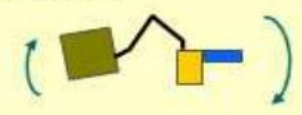

4) De-rotation of target \& chaser

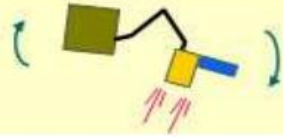

\section{APPLICATIONS}

\section{A. Space applications}

This project helps to create spaceflight safer for spacecraft and, in the event of crew members, for individuals on board. Results support future attempts to remove big non-operational spacecraft in order to help avoid the space station from having to dodge debris[14],[16],[18]. 


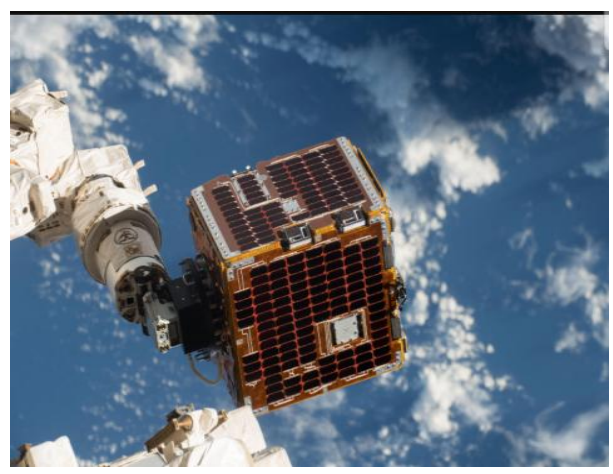

\section{B. EARTH APPLICATIONS}

Space debris collisions position essential space-based facilities on Earth at danger, such as navigation and cell phones[19],[20]. Reducing the danger of space crashes prevents these and many other essential facilities.

\section{CONCLUSION}

The JAXA Aerospace Research Directorate is studying an active space debris removal scheme using microsatellites and is exploring the applicability of EDT technology as its high-efficiency orbital transfer scheme. Prototyping and testing of each EDT hardware component is advancing. Although space debris management will pose certain hazards, early investment in maintaining the near-earth space environment is needed to safeguard the satellite technology that is so essential to the day-to-day activities of the global economy. by implementing steps to remove worldwide space debris, There is a critical chance to mitigate and minimize potential harm to space debris and to guarantee the sustainable development of the near-earth space environment.

\section{REFERENCES}

[1] Kongkham, D. \& Sundararajan, M. 2019, "Distributed wideband sensing method for faded dynamic spectrum access", International Journal of Innovative Technology and Exploring Engineering, vol. 8, no. 10, pp. 4309-4312.

[2] Balaji, S., John Paul Praveen, A. \& Mohanraj, R. 2019, "Recognizable proof and analysis of palm print in biometric authentication system using bayes techniques", International Journal of Innovative Technology and Exploring Engineering, vol. 8, no. 9 Special Issue 3, pp. 1126-1129.

[3] Kavitha, G., Priya, N., Velvizhi, R. \& Allin Geo, A.V. 2019, "Parallel computation in correspondence and signal processing", International Journal of Innovative Technology and Exploring Engineering, vol. 8, no. 9 Special Issue 3, pp. 1136-1139.

[4] Hema, R., Sundararajan, M. \& Balaji, S. 2019, "Smartphone control robot with automatic firing gun", International Journal of Innovative Technology and Exploring Engineering, vol. 8, no. 9 Special Issue 3, pp. 625-627.

[5] Kaliyamurthie, K.P., Sundar Raj, B., Velvizhi, R. \& Shanmugapriya, K 2019, "Dual band paper substrate CPW antenna for wireless applications", International Journal of Innovative Technology and Exploring Engineering, vol. 8, no. 9 Special Issue 3, pp. 605-608.

[6] Geo, A.V.A., Arunachalam, A.R., Michael, G. \& Elankavi, R. 2019 , "Evaluating architecture using compact modalities", International Journal of Innovative Technology and Exploring Engineering, vol. 8, no. 9 Special Issue 3, pp. 836-838.

[7] Theivasigamani, S., Jeyapriya, D. \& Anita Davamani, K. 2019, "Anamoly analyzing and exploring for wireless sensor networks", International Journal of Innovative Technology and Exploring Engineering, vol. 8, no. 9 Special Issue 3, pp. 1116-1118.

[8] Jeyapriya, D., Theivasigamani, S., Velvizhi, R. \& Nandhini, P. 2019, "Program detection in wireless feeler networks", International Journal of
Innovative Technology and Exploring Engineering, vol. 8, no. 9 Special Issue 3, pp. 1194-1195

[9] Gowri Sankaran, B., Karthik, B. \& Vijayaragavan, S.P. 2019, "Image compression utilizing wavelet transform", International Journal of Innovative Technology and Exploring Engineering, vol. 8, no. 10, pp. 4305-4308.

[10] Gowri Sankaran, B., Karthik, B. \& Vijayaragavan, S.P. 2019, "Weight ward change region plummeting change for square based image huffman coding", International Journal of Innovative Technology and Exploring Engineering, vol. 8, no. 10, pp. 4313-4316.

[11] Hema, R., Sundararajan, M. \& Balaji, S. 2019, "Smartphone control robot with automatic firing gun", International Journal of Innovative Technology and Exploring Engineering, vol. 8, no. 9 Special Issue 3, pp 625-627.

[12] Rangaswamy, K. \& Rajabhushanam, C. 2019, "Congestion control in wireless network using TCP friendly rate control (TFRC)", International Journal of Recent Technology and Engineering, vol. 8, no. 2 Special issue 3, pp. 1598-1602.

[13] Tamil Selvan, S. \& Sundararajan, M. 2019, "Performance Parameters of 3 Value 8t Cntfet Based Sram Cell Design Using H-Spice", International Journal of Recent Technology and Engineering, vol. 8, no. 2 Special issue 5, pp. 22-27.

[14] Vinoth, V.V. \& Kanniga, E. 2019, "Steganographical techniques in hiding text images - system", International Journal of Recent Technology and Engineering, vol. 8, no. 2, pp. 6535-6537.

[15] Saravana, S., Balaji, S., Arulselvi, S. \& John Paul Praveen, A. 2019, "Reliable power quality monitoring and protection system", International Journal of Innovative Technology and Exploring Engineering, vol. 8, no. 9 Special Issue 3, pp. 644-645.

[16] Sundaramoorthy, A. \& John Wiselin, M.C. 2019, "Single patch antenna with multiple feed", International Journal of Innovative Technology and Exploring Engineering, vol. 8, no. 9, pp. 1743-1747.

[17] Velavan, R., Bharanidharan, S. \& Sheeba, B. 2019, "EMF pollution Causes, effects and protection", International Journal of Innovative Technology and Exploring Engineering, vol. 8, no. 9 Special Issue 3, pp. 1166-1168.

[18] Veer, R.A., Arulselvi, S. \& Karthik, B. 2019, "Construction of ensemble square classification approaches in MIMO OFDM", International Journal of Engineering and Advanced Technology, vol. 8, no. 5, pp. 2039-2041.

[19] Agitha, W. \& Kaliyamurthie, K.P. 2019, "Improved energy efficient in WBAN using MAC with cloud computing", International Journal of Innovative Technology and Exploring Engineering, vol. 8, no. 8, pp. 2405-2408.

[20] Kastro, G.G. \& Wiselin, M.C.J. 2019, "Design and analysis of stub loaded resonator", International Journal of Recent Technology and Engineering, vol. 8, no. 1 Special Issue4, pp. 272-283.

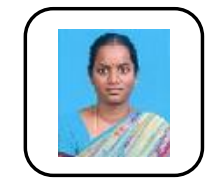

\section{AUTHORS PROFILE}

S. Philomina Assistant Professor, Department of Electronics and Communication Engineering, Bharath Institute of Higher Education and Research, Chennai, India.

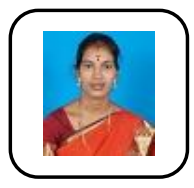

B. Hemalatha Assistant Professor, Department of Electronics and Communication Engineering, Bharath Institute of Higher Education and Research, Chennai, India.

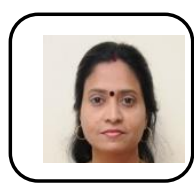

R. Hema Assistant Professor, Department of Electronics and Communication Engineering, Bharath Institute of Higher Education and Research, Chennai, India. 